\title{
Tetrahydroisoquinoline Phenols: Selective Estrogen Receptor Downregulator Antagonists with Oral Bioavailability in Rat
}

James S. Scott,* Andrew Bailey, Robert D. M. Davies, Sébastien L. Degorce, Philip A. MacFaul, Helen Gingell, Thomas Moss, Richard A. Norman, Jennifer H. Pink, Alfred A. Rabow, Bryan Roberts, and Peter D. Smith

Oncology iMed, AstraZeneca, Mereside, Alderley Park, Macclesfield, SK10 4TG, U.K.

\section{Supporting Information}
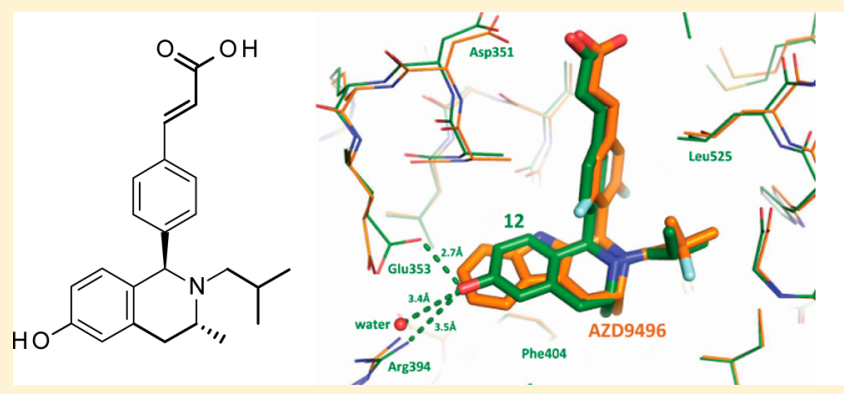

Phenotype

SERD

ER downregulation $\mathrm{IC}_{50}$

$1.3 \mathrm{nM}$

$\log \mathrm{D}_{7.4}$

1.7

Rat Bioavailability

$86 \%$

ABSTRACT: A series of tetrahydroisoquinoline phenols was modified to give an estrogen receptor downregulator-antagonist profile. Optimization around the core, alkyl side chain, and pendant aryl ring resulted in compounds with subnanomolar levels of potency. The phenol functionality was shown to be required to achieve highly potent compounds, but unusually this was compatible with obtaining high oral bioavailabilities in rat.

KEYWORDS: Estrogen receptor, antagonist, downregulator, bioavailable, phenol, tetrahydroisoquinoline

$\mathrm{T}_{\mathrm{t}}^{\mathrm{s}}$ he estrogen receptor (ER) is a clinically validated target for the treatment of hormonally driven breast cancer. ${ }^{1}$ The discovery of the ER antagonist tamoxifen represented a breakthrough in targeted cancer therapy with activity due to the formation of the 4-hydroxy metabolite, which mimics the phenol of the endogenous ligand estradiol (1). ${ }^{2}$ Considerable efforts have been made to develop alternative selective estrogen receptor modulators (SERMs) with a common issue encountered being that the phenol moiety required for high levels of binding to the estrogen receptor frequently leads to low bioavailability, often attributed to glucuronidation of the phenol. A notable exception is lasofoxifene (2), which exhibits low clearance and high oral bioavailability across species, attributed to its nonplanar topology reducing the rate of gut wall glucuronidation.

A further step change in treatment for hormonally driven breast cancer occurred with development of selective estrogen receptor downregulators (SERDs) such as fulvestrant. ${ }^{4}$ These molecules are capable of both antagonizing estrogen receptor driven cell proliferation as well as effecting a conformational change resulting in ubiquitinylation and degradation of the receptor. Although effective, the low oral bioavailability of fulvestrant means that it is therapeutically administered as a monthly intramuscular implant. Identification of an orally bioavailable SERD would therefore address an unmet medical need. We recently reported our initial attempts to develop a coumarin based series of SERDs. ${ }^{5}$ Further efforts in this area have resulted in the disclosure of $3(\mathrm{ARN}-810)^{6}$ and 4 (AZD9496), ${ }^{7}$ both of which are currently in Phase I clinical trials. Herein we report an investigation, carried out in parallel to the discovery of 4 , on a phenolic tetrahydroisoquinoline (THIQ) scaffold with the aim of identifying a potent, orally bioavailable SERD.

Phenolic THIQs with basic side chains have been previously shown to act as SERMs by groups at Pfizer $^{8}$ and Novartis ${ }^{9,10}$ with compounds such as $\mathbf{5}$ and $\mathbf{6}$ acting as antagonists at the receptors (Figure 1). Notably 6 was reported to have good bioavailability in $\operatorname{rat}(F=49 \%){ }^{10}$ We speculated that replacement of the basic substituent with an acrylic acid could confer the desired antagonist downregulator phenotype and may provide a way to generate orally bioavailable SERDs. We therefore prepared a series of THIQ derivatives with representative examples described below (Scheme 1).

The unsubstituted THIQ core of $\mathbf{3 2}$ was constructed via a Pictect-Spengler reaction between 3-(2-aminoethyl)phenol (30) and (E)-methyl 3-(4-formylphenyl)acrylate (31). Reductive amination allowed selective $N$-alkylation to 33 and subsequent ester hydrolysis gave 10, which was separated into enantiomers 10a and 10b using chiral chromatography (Scheme 1, steps a-c).

Received: October 23, 2015

Accepted: December 19, 2015

Published: December 19, 2015 


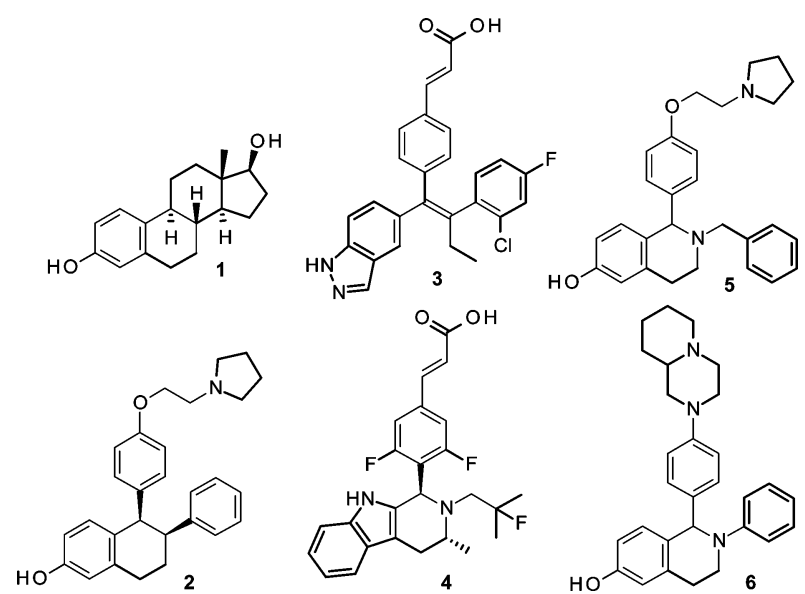

Figure 1. Chemical structures of estradiol (1), lasofoxifene (2), ARN810 (3), AZD9496 (4), and examples of THIQ SERMs from Pfizer (5) and Novartis (6).

For a series of 3-methyl substituted THIQs, chiral amine 34 was converted to the corresponding 4-bromo aryl amide 35 then subjected to a Bischler-Napieralski reaction to afford the THIQ core 36 as an inseparable mixture of trans/cis isomers (Scheme 1, steps $d-j$ ). A Heck reaction was used to convert the bromide to the acrylic ester 37 , and at this stage the mixture was separated to give enantiomerically pure trans isomer $37 \mathbf{a}$ in $42 \%$ yield over the two steps. Treatment with boron tribromide converted the 6-methoxy group to the free phenol and hydrolyzed the ester to the acid 12. Alternatively the ester could be selectively hydrolyzed using trifluoroacetic acid to give methyl ether 18. The des-phenol 17 was obtained by transiently protecting the acid of $\mathbf{1 2}$ as the silyl ester, converting the phenol to the triflate $\mathbf{3 8}$ and then treating with triethylsilane under palladium catalysis.
The dimethyl THIQ core 41 was constructed via a PictectSpengler reaction between $O$-benzyl protected phenethylamine 39 and aldehyde 40 with debenzylation of the phenol group occurring under the reaction conditions (Scheme 1, steps k-n). Silyl protection of the phenol gave $\mathbf{4 2}$ followed by $\mathrm{N}$-alkylation to 43. Treatment with lithium hydroxide hydrolyzed both the ester and silyl group to give $\mathbf{2 5}$, which was separated into individual enantiomers 25a and 25b using chiral chromatography.

Compounds were profiled in a suite of assays designed to identify compounds with the requisite ER downregulatorantagonist profile (Table 1). ${ }^{11}$ Physicochemical properties were also measured in an effort to highlight compounds suitable for oral dosing, including a glutathione (GSH) trapping assay designed to screen for the formation of reactive metabolites. ${ }^{12}$ With the addition of the acrylic acid functionality to the THIQ scaffold, $N$-phenyl (7) and $N$-benzyl (8) THIQs were shown to bind to the receptor and have a downregulator-antagonist phenotype. Exploration of the SAR around the phenyl ring identified that activity in the binding and downregulation assays could be increased by the addition of substituents such as $p$ $\mathrm{OCF}_{3}(9)$, consistent with previously reported $\mathrm{SAR}^{5}$ but the compounds were too lipophilic $\left(\log \mathrm{D}_{7.4} 3.7\right)$ and highly bound to plasma proteins (Rat PPB $0.06 \%$ free). As an alternative approach, we also examined $\mathrm{N}$-alkyl substituents such as ${ }^{\mathrm{i}} \mathrm{Bu}$ (10), which allowed a shift to lower lipophilicity space $\left(\log \mathrm{D}_{7.4}\right.$ 1.3) while maintaining downregulator-antagonist activity. Separation of the individual enantiomers showed that the activity resided predominantly in one isomer (10a), which is consistent with work carried out previously. ${ }^{13}$ Subsequent profiling showed reasonable free drug levels (Rat PPB 3.7\% free) and moderate clearance in rat hepatocytes $(38 \mu \mathrm{L} / \mathrm{min} /$ $10^{6}$ cells), which translated to a modest clearance in vivo (44 $\mathrm{mL} / \mathrm{min} / \mathrm{kg}$ ) and some oral levels (F 26\%) when dosed in a

Scheme 1. Synthesis of Key THIQs in the Unsubstituted, (3R)-Methyl, and 3,3-Dimethyl Series ${ }^{a}$
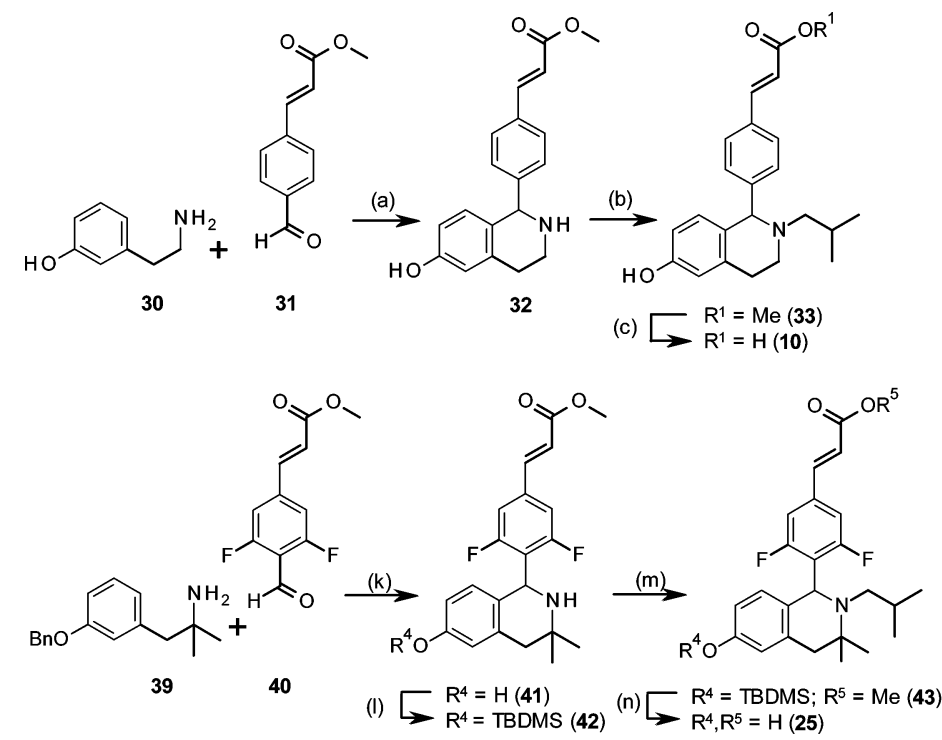
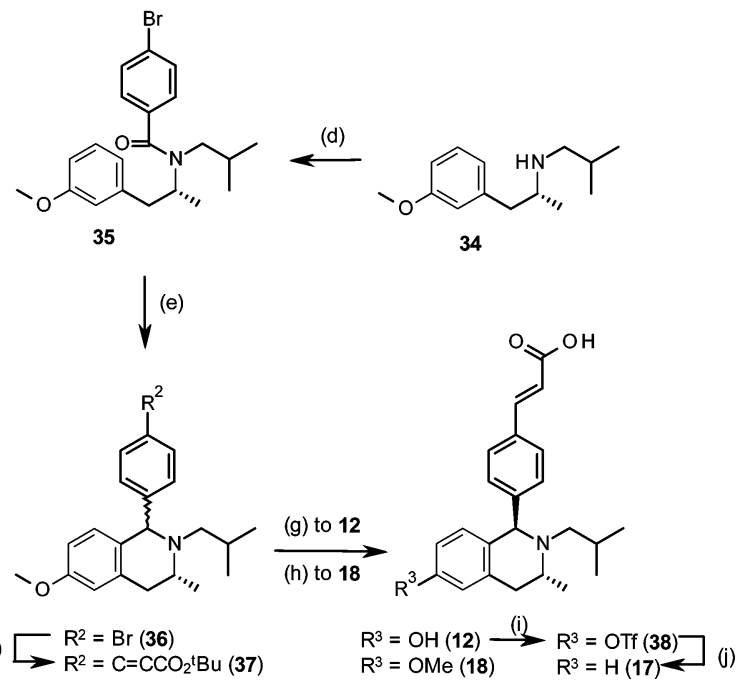

${ }^{a}$ Reagents and Conditions: (a) (i) $\mathrm{Et}_{3} \mathrm{~N}$, toluene, $90{ }^{\circ} \mathrm{C}, 2 \mathrm{~h}$; (ii) TFA, $90{ }^{\circ} \mathrm{C}, 1 \mathrm{~h}, 84 \%$; (b) $\mathrm{NaBH}(\mathrm{OAc}){ }_{3}, \mathrm{DCE} / \mathrm{AcOH}, \mathrm{r.t.}$, 71\%; (c) LiOH, $\mathrm{MeOH} / \mathrm{H}_{2} \mathrm{O}, 40{ }^{\circ} \mathrm{C}, 4 \mathrm{~h}, 91 \%$; (d) ${ }^{\mathrm{i}} \mathrm{Pr}_{2} \mathrm{NEt}$, 4-bromobenzoyl chloride, $\mathrm{DCM}$, r.t., $18 \mathrm{~h}, 84 \%$; (e) (i) $\mathrm{POCl}_{3}, 110{ }^{\circ} \mathrm{C}, 3 \mathrm{~h}$; (ii) $\mathrm{NaBH}$, $\mathrm{MeOH}^{\circ} 0{ }^{\circ} \mathrm{C}, 1$ h, 97\%; (f) ${ }^{t} \mathrm{Bu}$ acrylate, $\mathrm{PdCl}_{2}$ (dtbpf), $\mathrm{N}(\mathrm{Me}) \mathrm{Cy}_{2}, \mathrm{Bu}_{4} \mathrm{NCl}, \mathrm{MeCN}, 150{ }^{\circ} \mathrm{C}, 45 \mathrm{~min}, 42 \%$ trans, $25 \%$ cis; (g) $\mathrm{BBr}_{3}, \mathrm{DCM},-78{ }^{\circ} \mathrm{C}$ to r.t., $3 \mathrm{~h}, 85 \%$; (h) TFA, DCM, r.t., 1 h, 56\%; (i) (i) TBDMSCl, $N$-methylmorpholine, THF, r.t., $3 \mathrm{~h}$; $(i i) \mathrm{PhN}\left(\mathrm{SO}_{2} \mathrm{CF}_{3}\right)_{2}, \mathrm{Et}_{3} \mathrm{~N}, \mathrm{DCM}, \mathrm{r} . t ., 18$ h, $65 \%$; $(\mathrm{j})$ $\mathrm{Pd}(\mathrm{OAc})_{2}, \mathrm{Et}_{3} \mathrm{SiH},\left(\mathrm{Ph}_{2} \mathrm{P}\right)_{2} \mathrm{C}_{3} \mathrm{H}_{6}, \mathrm{DMF}, 6{ }^{\circ} \mathrm{C}, 6 \mathrm{~h}, 36 \%$; (k) (i) $\mathrm{K}_{3} \mathrm{PO}_{4}, \mathrm{MeCN} / \mathrm{H}_{2} \mathrm{O}, 50{ }^{\circ} \mathrm{C}, 18 \mathrm{~h}$; (ii) TFA, $100{ }^{\circ} \mathrm{C}, \mathrm{MW}, 2 \mathrm{~h}, 46 \%$; (l) TBDMSCl, DMAP, pyridine, reflux, 7 h, 80\%; (m) ${ }^{i}$ BuOTf, $\mathrm{iPr}_{2} \mathrm{NEt}$, 1,4-dioxane, r.t., 24 h, 84\%; (n) $\mathrm{LiOH}, \mathrm{MeOH} / \mathrm{THF} / \mathrm{H}_{2} \mathrm{O}$, r.t., 5 h, $95 \%$. 
Table 1. Data for Variation of N-Substitution on the THIQ Core

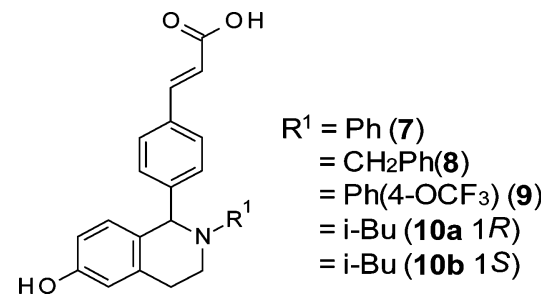

\begin{tabular}{|c|c|c|c|c|c|c|}
\hline Cpd & $\begin{array}{l}\text { ER bind } \\
\mathrm{IC}_{50} \\
(\mathrm{nM})^{a}\end{array}$ & $\begin{array}{l}\text { ER DR } \\
\text { IC }_{50} \\
(\mathrm{nM})^{b}\end{array}$ & $\log D^{c}$ & $\begin{array}{l}\text { Rat/Hu } \\
\text { free }^{d}\end{array}$ & $\begin{array}{c}\mathrm{Rat} / \mathrm{Hu} \\
\text { heps } \\
\mathrm{Cl}_{\text {int }}{ }^{e}\end{array}$ & $\begin{array}{l}\text { GSH } \\
\text { ratio }^{f}\end{array}$ \\
\hline 7 & 4.7 & 71 & 2.4 & $1.2 / 1.2$ & $87 / 67$ & 0.25 \\
\hline 8 & 36 & 90 & 2.2 & $1.3 / 0.7$ & $40 / 150$ & 0.20 \\
\hline 9 & 0.96 & 35 & 3.7 & $0.06 / 0.06$ & $20 / 11$ & 0.56 \\
\hline $10 \mathrm{a}$ & 26 & 4.4 & 1.3 & $3.7 / 6.3$ & $38 / 38$ & $<0.04$ \\
\hline $10 \mathrm{~b}$ & 1100 & 42 & 1.4 & $8.7 / 1.9$ & $49 / 4$ & 0.06 \\
\hline
\end{tabular}

${ }^{a}$ ER binding based on $n \geq 2$ with SEM within 0.2 units except for $10 \mathrm{~b}$ $(n=1) .{ }^{b}$ ER downregulation based on $n \geq 3$ with SEM within 0.2 units. ${ }^{c} \log \mathrm{D}_{7.4}$ determined by shake flask method. ${ }^{d}$ Determined from DMSO stock solution by equilibrium dialysis in $10 \%$ plasma from Alderley Park Han Wistar rats or $10 \%$ human plasma supplied by Quintiles. ${ }^{e}$ Rate of metabolism $\left(\mu \mathrm{L} / \mathrm{min} / 10^{6}\right.$ cells $)$ determined from DMSO stock solution in isolated rat or human cryopreserved hepatocytes diluted to $1 \times 10^{6}$ cells $/ \mathrm{mL} .{ }^{f}$ Amount of GSH adduct formed relative to clozapine as described in ref 12 .

pharmacokinetic study to Han Wistar rats (Table 6). Given the high potency in the downregulation assay $\left(\mathrm{IC}_{50} 4.4 \mathrm{nM}\right)$ and the encouraging oral exposure in rat we felt that 10a represented a promising hit for further optimization.

Placement of a methyl group at varying positions around the core was investigated as a way of mapping out the SAR (Table 2). 1-Methyl substitution resulted in an enantiomeric set of compounds, which again showed the SERD activity predominantly resided in one enantiomer (11a) ${ }^{14}$ Despite a large increase in lipophilicity associated with this change $\left(\Delta \log \mathrm{D}_{7.4}+\right.$ $0.9)$, the potency dropped slightly $\left(\Delta \mathrm{pIC}_{50}-0.4\right)$. In contrast, 3-(R)-methyl substitution (12) added less lipophilicity

Table 2. Data for Methyl Substitution of the THIQ Core

\begin{tabular}{|c|c|c|c|c|c|c|c|}
\hline & & Cpd & $\overline{\mathrm{R}^{1}}$ & $\mathrm{R}^{2}$ & $\mathrm{R}^{3}$ & $\overline{\mathrm{R}^{4}}$ & $\overline{\mathrm{R}^{5}}$ \\
\hline & & $10 a$ & $\mathrm{H}$ & $\mathrm{H}$ & $\mathrm{H}$ & $\mathrm{H}$ & $\mathrm{H}$ \\
\hline & & 11a & Me & $\mathrm{H}$ & $\mathrm{H}$ & $\mathrm{H}$ & $\mathrm{H}$ \\
\hline & & 12 & $\mathrm{H}$ & Me & $\mathrm{H}$ & $\mathrm{H}$ & $\mathrm{H}$ \\
\hline & & 13 & Me & Me & $\mathrm{H}$ & $\mathrm{H}$ & $\mathrm{H}$ \\
\hline & & $14 a$ & $\mathrm{H}$ & Me & Me & $\mathrm{H}$ & $\mathrm{H}$ \\
\hline & & 15 & $\mathrm{H}$ & $\mathrm{H}$ & $\mathrm{H}$ & Me & $\mathrm{H}$ \\
\hline & & 16 & $\mathrm{H}$ & $\mathrm{H}$ & $\mathrm{H}$ & $\mathrm{H}$ & Me \\
\hline Cpd & $\begin{array}{l}\text { ER bind } \\
\mathrm{IC}_{50}(\mathrm{nM})\end{array}$ & $\begin{array}{c}\text { ER DR } \\
\mathrm{IC}_{50}(\mathrm{nM})\end{array}$ & $\log \mathrm{D}$ & $\begin{array}{l}\text { Rat/1 } \\
\% \text { fr }\end{array}$ & & $\begin{array}{l}\text { Rat/Hu } \\
\text { heps } \mathrm{Cl}_{\text {int }}\end{array}$ & $\begin{array}{l}\text { GSH } \\
\text { ratio }\end{array}$ \\
\hline $10 a$ & 26 & 4.4 & 1.3 & $3.7 / 6$ & & $38 / 38$ & $<0.04$ \\
\hline $11 a$ & 44 & 11 & 2.2 & $1.9 / \mathrm{C}$ & & $33 / 40$ & 0.16 \\
\hline 12 & 19 & 1.3 & 1.7 & $7.5 / 7$ & & $22 / 33$ & 0.11 \\
\hline 13 & 12 & $5.5^{a}$ & 2.7 & $1.3 / 1$ & & $15 / 18$ & 0.66 \\
\hline $14 a$ & 39 & 7.0 & 1.5 & $11 / 3$ & & $7 / 6$ & 0.17 \\
\hline 15 & 610 & 170 & 1.6 & $6.3 / 2$ & & $32 / 9$ & 0.06 \\
\hline 16 & 160 & 43 & 1.8 & $8.8 / 5$ & & $17 / 17$ & 0.09 \\
\hline
\end{tabular}

${ }^{a}$ Result based on $n=2$, SEM 0.14 .
$\left(\Delta \log \mathrm{D}_{7.4}+0.4\right)$ but showed a proportionate increase in activity in the downregulation assay $\left(\Delta \mathrm{pIC}_{50}+0.5\right)$.

We re-examined 1-methyl substitution in combination with the 3-(R)-methyl (13) on the basis the methyl groups may have a conformational influence on each other, but found a similar rise in lipophilicity $\left(\Delta \log \mathrm{D}_{7.4}+1.0\right)$ and reduction in potency $\left(\Delta \mathrm{pIC}_{50}-0.6\right)$ similar to that seen with 10a and 11a. The GSH trapping increased with 13 , and this was attributed to the increased lipophilicity. Addition of a second methyl group at the 3-position resulted in a compound with slightly lower $\log \mathrm{D}$ $(-0.2$ relative to 12$)$ with one of the enantiomeric pairs $(\mathbf{1 4 a})$ significantly more active in the binding assay. ${ }^{15}$ Notably the effect of moving to the gem-dimethyl substitution led to a marked reduction in turnover in both human and rat hepatocytes compared to the unsubstituted or monomethyl analogues.

An X-ray crystal structure of $10 a$ in complex with a construct of the ER $\alpha$ ligand binding domain (Figure 2a) showed the phenol group interacting with a conserved water and both elements of a salt bridge formed between residues Glu-351:Arg394 with distances of $3.1 / 2.6 / 3.1 \AA$ consistent with formation of a strong hydrogen bond network. Structures of 11 a and 12 (Figure $2 \mathrm{~b}$ ) showed minimal perturbation of the tetrahydroisoquinoline phenol with the $3-(R)$-methyl group filling the "Phe-404:Phe-425 lipophilic hole" as described previously. Methyl substitution ortho to the phenol led to a reduction in potency, more marked in the 5-methyl (15) than the 7-methyl (16) compound. This was consistent with a significant shift in the position of the core to accommodate the 5-methyl substitution as shown in Figure $2 \mathrm{c}$ and a corresponding lengthening of the interactions of the phenol with the water and salt bridge (3.6/2.7/3.6 $)$ ). Compounds 12, 13, and 14a were profiled in rats and showed acceptable pharmacokinetic profiles with improved bioavailability relative to 10a (Table 6).

In order to evaluate the contribution of the phenol to the potency of 12 , we made the corresponding compounds where the phenol was deleted (17) or capped with a methyl group (18) (Table 3). As expected, both compounds lost significant activity in both the binding and downregulation assays consistent with loss of the phenol interaction seen in the Xray crystal structures and our previously reported findings. ${ }^{5}$ Notably, the compounds without the phenol showed no activity in a GSH trapping assay, whereas phenol $\mathbf{1 2}$ showed a small but reproducible signal potentially indicating a reactive metabolite risk.

In the 3-(R)-methyl series, exemplified by 12 , we elected to examine the SAR around the $N$-alkyl substituent and investigate di-ortho fluorination of the pendant aryl ring as a potential way to increase potency based on previous work on an alternative scaffold. ${ }^{7}$ We initially looked to reduce lipophilicity by introduction of an ether to the 3-position of the $\mathrm{N}$-alkyl chain (19). This resulted in a lowering of $\log \mathrm{D}\left(\Delta \log \mathrm{D}_{7.4}-0.7\right.$ relative to 12) and reduced the amount of GSH trapping observed but was lower in potency. Introduction of di-ortho fluorine substituents (20) did have the desired effect of increasing potency but unfortunately led to increases in both rat and human hepatocyte clearances. Addition of a 3-F to the alkyl chain (21) and the di-ortho fluorinated aryl analogue (22) were both subnanomolar downregulators but suffered from high hepatocyte clearances. Moving the fluorine to the 2-position of the alkyl chain (23) further increased the potency but did not ameliorate the high metabolism or GSH signal seen in vitro. As an alternative approach, we elected to revisit the $p-\mathrm{OCF}_{3}$ aryl 


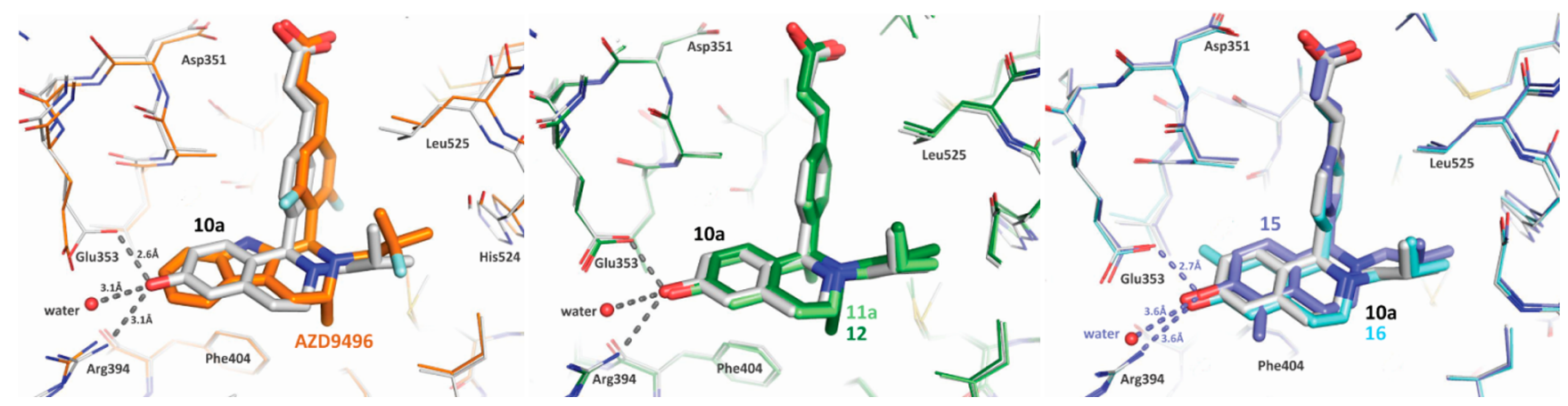

Figure 2. X-ray crystallography of THIQs bound to the ER $\alpha$ ligand binding domain construct; (a) 10a (pdb code 5fqr) overlaid with AZD9496 (pdb code 5acc); (b) 10a overlaid with 11a (pdb code 5fqs) and 12 (pdb code 5fqp); (c) 10a overlaid with 15 (pdb code 5fqv) and 16 (pdb code 5fqt).

Table 3. Data for Phenol Replacement in the THIQ Core

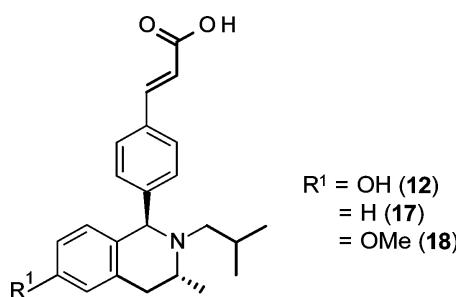

\begin{tabular}{ccccccc} 
Cpd & $\begin{array}{c}\text { ER bind } \\
\mathrm{IC}_{50}(\mathrm{nM})\end{array}$ & $\begin{array}{c}\mathrm{ER} \mathrm{DR} \\
\mathrm{IC}_{50}(\mathrm{nM})\end{array}$ & $\log \mathrm{D}$ & $\begin{array}{c}\mathrm{Rat} / \mathrm{Hu} \\
\% \text { free }\end{array}$ & $\begin{array}{c}\mathrm{Rat} / \mathrm{Hu} \\
\text { heps } \mathrm{Cl}_{\text {int }}\end{array}$ & $\begin{array}{c}\mathrm{GSH} \\
\text { ratio }\end{array}$ \\
$\mathbf{1 2}$ & 19 & 1.3 & 1.7 & $7.5 / 7.0$ & $22 / 33$ & 0.11 \\
$\mathbf{1 7}$ & 230 & 82 & 2.5 & $1.6 / 2.1$ & $24 / 45$ & $<0.04$ \\
$\mathbf{1 8}$ & 390 & 160 & 2.3 & $3.4 / 2.0$ & $43 / 56$ & $<0.04$ \\
\hline
\end{tabular}

substituent in the methyl series (24) in the hope that the increased lipophilicity would result in reduced free drug levels and consequently the compound would be protected from metabolism. This was effective in that, despite the increased lipophilicity, the compound showed low turnover in both rat and human hepatocytes and had excellent pharmacokinetics in rat with low clearance ( $\mathrm{Cl} 4.2 \mathrm{~mL} / \mathrm{min} / \mathrm{kg}$ ) and high bioavailability (F 79\%) (Table 6). Despite the high lipophilicity $\left(\log \mathrm{D}_{7.4} 4.2\right)$, the potency was lower than seen with the alkyls and the GSH signal remained.

Based on the observation that the 3,3-gem-dimethyl substituted core was less potent but more metabolically stable then the 3-(R)-methyl core (14a vs $\mathbf{1 2})$, we profiled some combinations of optimal $\mathrm{N}$-alkyl substituents both with and without di-ortho fluorination in the aryl ring. In each case the data for the most potent enantiomer is shown. ${ }^{15}$ These compounds were generally less potent than the corresponding matched pairs in the $3-(R)$-methyl series ${ }^{16}$ but in most cases were more metabolically stable in hepatocytes. Two examples (25a and 27a) were profiled in a rat pharmacokinetic study and both showed high bioavailability $(F>70 \%)$. Unfortunately, the in vitro GSH signal was seen with all examples profiled consistent with the presence of the phenol.

As a representative example of this series, compound 12 was profiled further (Table 7 ). The $\mathrm{p} K_{\mathrm{a}}$ of the basic nitrogen was found to be 8.6 and the presence of this cation together with the anion of the acrylic acid $\left(\mathrm{pK}_{\mathrm{a}} 4\right)$ indicates that 12 will be predominantly zwitterionic at neutral $\mathrm{pH} .{ }^{17}$ The $\mathrm{p} K_{\mathrm{a}}$ of the phenol was measured to be 10.4. The compound showed good aqueous solubility and high membrane flux in a Caco-2 permeability assay and no significant efflux. No activity was observed against the hERG ion channel $\left(\mathrm{IC}_{50}>30 \mu \mathrm{M}\right)$ or five
Table 4. Data for Compounds with the 3-(R)-Methyl THIQ Core

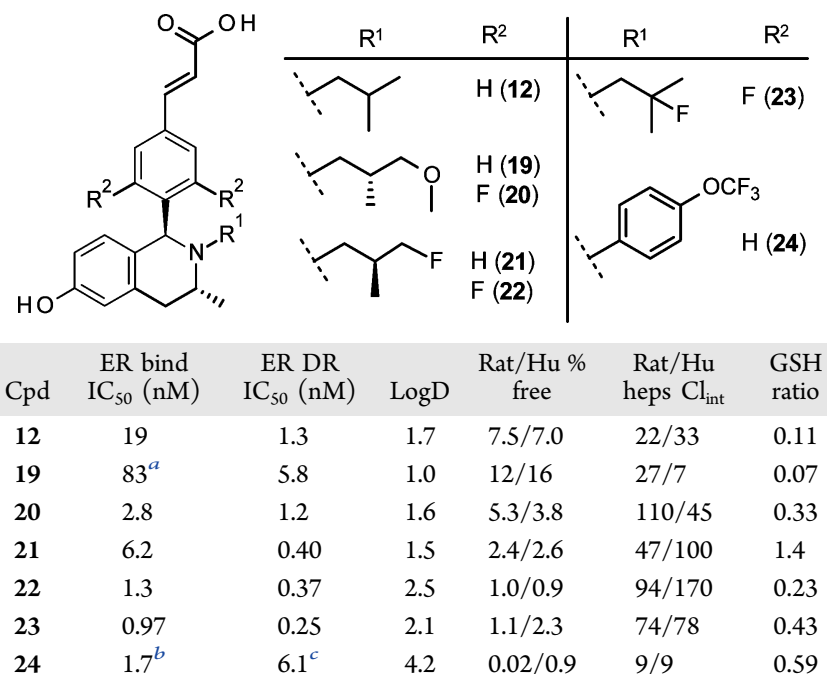

${ }^{a}$ Result based on $n=4$, SEM $0.22 .{ }^{b}$ Result based on $n=3$, SEM 0.29 . ${ }^{c}$ Result based on $n=3$, SEM 0.25 .

Table 5. Data for Compounds with the 3,3-gem-DimethylTHIQ Core

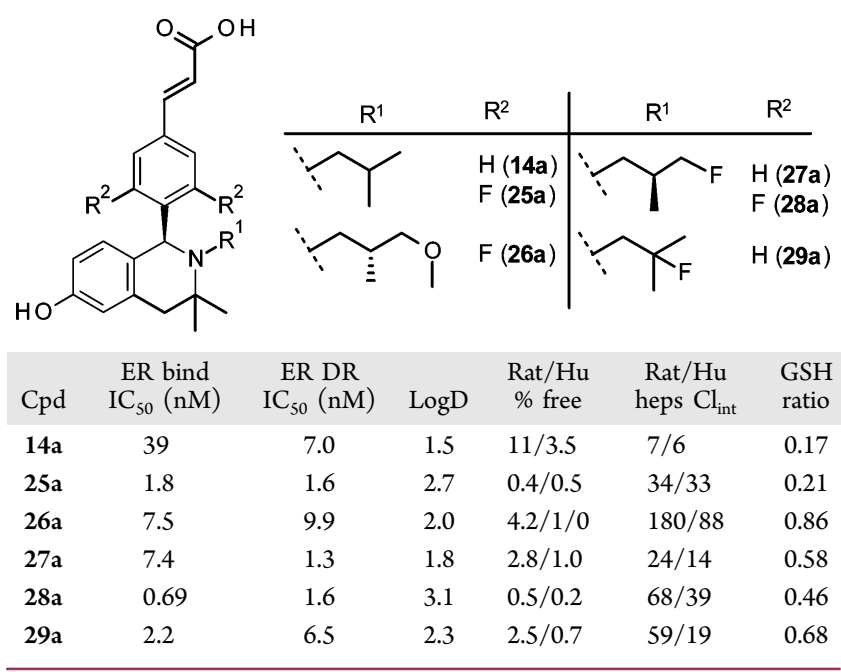

isoforms of the cytochrome P450 enzymes $\left(\mathrm{IC}_{50}>30 \mu \mathrm{M}\right)$ and the compound had a clean profile $\left(\mathrm{IC}_{50}>30 \mu \mathrm{M}\right)$ against a panel of 157 other targets at Cerep with only four weak hits. ${ }^{18}$ 


\section{Table 6. Rat Pharmacokinetic Parameters for THIQs}

$\begin{array}{lccccc}\text { Cpd } & \begin{array}{c}\mathrm{Clp}^{a} \\ (\mathrm{~mL} / \mathrm{min} / \mathrm{kg})\end{array} & \begin{array}{c}\text { Vdss } \\ (\mathrm{L} / \mathrm{kg})\end{array} & \begin{array}{c}\text { PO } t_{1 / 2} \\ (\mathrm{~h})\end{array} & \begin{array}{c}\mathrm{IV} t_{1 / 2} \\ (\mathrm{~h})\end{array} & \begin{array}{c}\text { bioavailability } F \\ (\%)\end{array} \\ \mathbf{1 0 a} & 44 & 0.5 & 3.0 & 0.2 & 26 \\ 12 & 49 & 0.6 & 3.9 & 0.2 & 86 \\ 13 & 19 & 1.6 & 5.6 & 2.4 & 33 \\ \mathbf{1 4 a} & 21 & 5.9 & 7.4 & 5.8 & 66 \\ 19 & 63 & 0.6 & 1.9 & 0.2 & 3 \\ \mathbf{2 4} & 4.2 & 1.1 & 6.7 & 4.2 & 79\end{array}$

${ }^{a}$ Compounds were dosed intravenously at $0.5 \mathrm{mg} / \mathrm{kg}$ in $5 \% \mathrm{DMSO} /$ 95\% hydroxylpropyl $\beta$-cyclodextrin or $10 \%$ DMA/90\% Captisol and orally as $1 \mathrm{mg} / \mathrm{kg}$ using a $0.1 \% \mathrm{HMPC} /$ tween suspension or $10 \%$ $\mathrm{DMSO} / 90 \%$ cyclodextrin solution. The data shown is the mean of the data generated in two male rats.

Table 7. Physicochemical Parameters for THIQ 12

$\begin{array}{rcccccc}\begin{array}{c}\text { acid } \\ \mathrm{pK}_{\mathrm{a}}^{a}\end{array} & \begin{array}{c}\text { phenol } \\ \mathrm{pK}_{\mathrm{a}}^{a}\end{array} & \begin{array}{c}\text { base } \\ \mathrm{pK}_{\mathrm{a}}^{a}\end{array} & \begin{array}{c}\text { solubility } \\ (\mu \mathrm{M})^{b}\end{array} & \begin{array}{c}\text { Caco-2 } \\ \mathrm{Papp}^{c}\end{array} & \begin{array}{c}\mathrm{hERG} \mathrm{IC} \\ (\mu \mathrm{M})^{d}\end{array} & \begin{array}{c}\text { CYPs IC } \\ (\mu \mathrm{M})^{e}\end{array} \\ 4.0 & 10.4 & 8.6 & >1500 & \begin{array}{c}15(\mathrm{AB}) \\ 11(\mathrm{BA})\end{array} & >30 & \text { all }>30 \\ & & & & & \end{array}$

${ }^{a} K_{\mathrm{a}}$ measured using UV absorption (Sirius) in $0.1 \mathrm{M}$ potassium chloride at $20{ }^{\circ} \mathrm{C}$. ${ }^{b}$ Solubility of compounds in aqueous phosphate buffer at $\mathrm{pH} 7.4$ after $24 \mathrm{~h}$ at $25{ }^{\circ} \mathrm{C}$. ${ }^{\circ}$ Compounds were incubated at 10 $\mu \mathrm{M}$ in cultured Caco-2 cells. Permeability was measured in both the apical to basolateral (A to B) and basolateral to apical (B to A) directions. ${ }^{d}$ Inhibition of the hERG tail current was measured using a plate-based planar patch clamp system (IonWorks). ${ }^{19}{ }^{e}$ Inhibition of cytochrome P450 enzymes $\mathrm{IC}_{50}$.

In conclusion, we have demonstrated that by inclusion of an acrylic acid motif, an ER downregulator-antagonist profile could be achieved in a series of tetrahydroisoquinoline phenols. Optimization around the core, alkyl side chain, and pendant aryl ring resulted in compounds with subnanomolar levels of potency. The phenol functionality was shown to be required to achieve highly potent compounds, but unusually this was compatible with obtaining high oral bioavailabilities in rat across a range of lipophilicity. These compounds were observed to trap glutathione in an in vitro trapping assay, potentially indicative of a reactive metabolite risk and, as a consequence, were not progressed. Further studies on efforts to reduce this risk will be reported in due course.

\section{ASSOCIATED CONTENT}

\section{S Supporting Information}

The Supporting Information is available free of charge on the ACS Publications website at DOI: 10.1021/acsmedchemlett.5b00413.

Experimental procedures for the synthesis of representative compounds together with biological data and associated errors (PDF)

\section{AUTHOR INFORMATION}

\section{Corresponding Author}

*Tel: +44 (0)1625 232567. Fax: +44 (0)1625 516667. E-mail: jamie.scott@astrazeneca.com.

\section{Author Contributions}

The manuscript was written through contributions of all authors. All authors have given approval to the final version of the manuscript.

Notes

The authors declare no competing financial interest.

\section{ACKNOWLEDGMENTS}

We thank the Alderley Park purification group for purification and structural characterisation of some final compounds. Chris Phillips is thanked for assistance with the deposition of crystal structures.

\section{ABBREVIATIONS}

$\mathrm{DR}$, downregulation; ER, estrogen receptor; GSH, glutathione; $\mathrm{PPB}$, plama protein binding; SAR, structure-activity relationship; SERD, selective estrogen receptor downregulator; SERM, selective estrogen receptor modulator; THIQ tetrahydroisoquinoline

\section{REFERENCES}

(1) Ariazi, E. A.; Jordan, V. C. Estrogen receptors as therapeutic targets in breast cancer. In Nuclear Receptors as Drug Targets. Eckhard, O., Weinmann, H., Eds.; Wiley-VCH Verlag GmbH: Weinheim, Germany, 2008; pp 127-199.

(2) Jordan, V. C. Tamoxifen: a most unlikely pioneering medicine. Nat. Rev. Drug Discovery 2003, 2, 205-213.

(3) Rosati, R. L.; Jardine, P. D. S.; Cameron, K. O.; Thompson, D. D.; Ke, H. Z.; Toler, S. M.; Brown, T. A.; Pan, L. C.; Ebbinghaus, C. F.; Reinhold, A. R.; Elliott, N. C.; Newhouse, B. N.; Tjoa, C. M.; Sweetnam, P. M.; Cole, M. J.; Arriola, M. W.; Gauthier, J. W.; Crawford, D. T.; Nickerson, D. F.; Pirie, C. M.; Qi, H.; Simmons, H. A.; Tkalcevic, G. T. Discovery and preclinical pharmacology of a novel, potent, nonsteroidal estrogen receptor agonist/antagonist, CP-336156, a diaryltetrahydronaphthalene. J. Med. Chem. 1998, 41, 2928-2931.

(4) Johnston, S. J.; Cheung, K. L. Fulvestrant - a novel endocrine therapy for breast cancer. Curr. Med. Chem. 2010, 17, 902-914.

(5) Degorce, S. L.; Bailey, A.; Callis, R.; De Savi, C.; Ducray, R.; Lamont, G.; MacFaul, P. A.; Maudet, M.; Martin, S.; Morgentin, R.; Norman, R. A.; Peru, A.; Pink, J.; Plé, P.; Roberts, B.; Scott, J. S. Investigation of (E)-3-[4-(2-oxo-3-aryl-chromen-4-yl)oxyphenyl]acrylic acids as Oral Selective Estrogen Receptor Down-Regulators. J. Med. Chem. 2015, 58 (8), 3522-3533.

(6) Lai, A.; Kahraman, M.; Govek, S.; Nagasawa, J.; Bonnefous, C.; Julien, J.; Douglas, K.; Sensintaffar, J.; Lu, N.; Lee, K.-j.; Aparicio, A.; Kaufman, J.; Qian, J.; Shao, G.; Prudente, R.; Moon, M. J.; Joseph, J. D.; Darimont, B.; Brigham, D.; Grillot, K.; Heyman, R.; Rix, P. J.; Hager, J. H.; Smith, N. D. Identification of GDC-0810 (ARN-810), an Orally Bioavailable Selective Estrogen Receptor Degrader (SERD) that Demonstrates Robust Activity in Tamoxifen-Resistant Breast Cancer Xenografts. J. Med. Chem. 2015, 58 (12), 4888-4904.

(7) De Savi, C.; Bradbury, R. H.; Rabow, A. A.; Norman, R. A.; de Almeida, C.; Andrews, D. M.; Ballard, P.; Buttar, D.; Callis, R. J.; Currie, G. S.; Curwen, J. O.; Davies, C. D.; Donald, C. S.; Feron, L. J. L.; Gingell, H.; Glossop, S. C.; Hayter, B. R.; Hussain, S.; Karoutchi, G.; Lamont, S. G.; MacFaul, P.; Moss, T. A.; Pearson, S. E.; Tonge, M.; Walker, G. E.; Weir, H. M.; Wilson, Z. Optimization of a novel binding motif to $(E)-3$-(3,5-difluoro-4-((1R,3R)-2-(2-fluoro-2-methylpropyl)3-methyl-2,3,4,9-tetrahydro-1H-pyrido[3,4-b]indol-1-yl)phenyl)acrylic acid (AZD9496), a potent and orally bioavailable selective estrogen receptor downregulator and antagonist. J. Med. Chem. 2015, 58 (20), $8128-8140$.

(8) Chesworth, R.; Zawistoski, M. P.; Lefker, B. A.; Cameron, K. O.; Day, R. F.; Mangano, F. M.; Rosati, R. L.; Colella, S.; Petersen, D. N.; Brault, A.; Lu, B.; Pan, L. C.; Perry, P.; Ng, O.; Castleberry, T. A.; Owen, T. A.; Brown, T. A.; Thompson, D. D.; DaSilva-Jardine, Paul Tetrahydroisoquinolines as subtype selective estrogen agonists/ antagonists. Bioorg. Med. Chem. Lett. 2004, 14 (11), 2729-2733.

(9) Renaud, J.; Bischoff, S. F.; Buhl, T.; Floersheim, P.; Fournier, B.; Halleux, C.; Kallen, J.; Keller, H.; Schlaeppi, J.-M.; Stark, W. Estrogen Receptor Modulators: Identification and Structure-Activity Relationships of Potent ER $\alpha$-Selective Tetrahydroisoquinoline Ligands. J. Med. Chem. 2003, 46 (14), 2945-2957. 
(10) Renaud, J.; Bischoff, S. F.; Buhl, T.; Floersheim, P.; Fournier, B.; Geiser, M.; Halleux, C.; Kallen, J.; Keller, H.; Ramage, P. Selective Estrogen Receptor Modulators with Conformationally Restricted Side Chains. Synthesis and Structure-Activity Relationship of $\operatorname{ER} \alpha$ Selective Tetrahydroisoquinoline Ligands. J. Med. Chem. 2005, 48 (2), 364-379.

(11) Callis, R.; Rabow, A.; Tonge, M.; Bradbury, R.; Challinor, M.; Roberts, K.; Jones, K.; Walker, G. A Screening Assay Cascade to Identify and Characterize Novel Selective Estrogen Receptor Downregulators (SERDs). J. Biomol. Screening 2015, 20 (6), 748-759.

(12) GSH trapping was assessed in human liver microsomes with trapping reported as a ratio to a positive control, clozapine, as detailed in Lenz, E. M.; Martin, S.; Schmidt, R.; Morin, P.-E.; Smith, R.; Weston, D. J.; Bayrakdarian, M. Reactive Metabolite Trapping Screens and Potential Pitfalls: Bioactivation of a Homomorpholine and Formation of an Unstable Thiazolidine Adduct. Chem. Res. Toxicol. 2014, 27, 968-980.

(13) The configuration of the stereocenter of 10a was assigned as (1R) based on the X-ray crystal structure of 10a in complex with the protein. Additional support for this was based on the fact that $\mathbf{1 2}$ has an absolute configuration of $(1 R, 3 R)$.

(14) The configuration of the stereocenter of 11a was assigned as (1R) based on the X-ray crystal structure of $11 \mathrm{a}$ in complex with the protein. The enantiomeric compound $\mathbf{1 1} \mathbf{b}$ showed lower activity in both the binding $\left(\mathrm{IC}_{50} 5.8 \mu \mathrm{M}\right)$ and downregulation $\left(\mathrm{IC}_{50} 590 \mathrm{nM}\right)$ assay.

(15) The configuration of the stereocenter of $\mathbf{1 4 a}$ was assigned as (1R) based on the X-ray crystal structure of 14a in complex with the protein. The enantiomeric compound $\mathbf{1 4 b}$ showed lower activity in the binding assay $\left(\mathrm{IC}_{50} 960 \mathrm{nM}\right)$. By analogy, the compounds in Table 5 $(25 a-29 a)$ were also assigned with this stereochemistry.

(16) For the four matched pairs in this paper the mean $\Delta \mathrm{pIC}_{50}$ for the transform $3 R$-methyl to 3,3-gem-dimethyl was -0.2 in the binding assay and -0.7 in the downregulation assay.

(17) Calculations based on these $\mathrm{p} K_{\mathrm{a}}$ values indicate the compound would be expected to exist predominantly as a zwitterion (95\%) with a small amount of anion (5\%) present at neutral $\mathrm{pH}$.

(18) Compound $\mathbf{1 2}$ showed weak activity in a Cerep screen against the following targets; delta 2 opioid receptor $\left(\mathrm{IC}_{50} 13 \mu \mathrm{M}\right)$; opioid receptor mu $1\left(\mathrm{IC}_{50} 12 \mu \mathrm{M}\right)$; bradykinin receptor $2\left(\mathrm{IC}_{50} 20 \mu \mathrm{M}\right)$; adenosine receptor $\mathrm{A} 1\left(\mathrm{IC}_{50} 29 \mu \mathrm{M}\right)$.

(19) Bridgland-Taylor, M. H.; Hargreaves, A. C.; Easter, A.; Orme, A.; Henthorn, D. C.; Ding, M.; Davis, A. M.; Small, B. G.; Heapy, C. G.; Abi-Gerges, N.; Persson, F.; Jacobson, I.; Sullivan, M.; Albertson, N.; Hammond, T. G.; Sullivan, E.; Valentin, J.-P.; Pollard, C. E. Optimisation and validation of a medium-throughput electrophysiology-based hERG assay using IonWorks HT. J. Pharmacol. Toxicol. Methods 2006, 54, 189-199. 